\section{Woody species recruitment under monospecific plantations of pioneer trees - facilitation or inhibition?}

\author{
Débora Francieli Vercelino da Trindade ${ }^{(1)}$, Geraldo Ceni Coelho ${ }^{(2)}$
}

The successional model of forest restoration is based on the facilitation process, in which the establishment of pioneer tree species favors the late successional tree species. We tested the hypothesis of facilitation through a case study, comparing tree species diversity in the understory of two Neotropical native tree species plantations, Trema micrantha (L.) Blüme (Cannabaceae) and Schinus molle L. (Anacardiaceae). Results obtained under the plantations were compared with an adjacent area under spontaneous secondary succession, analyzing the ligneous plant diversity, soil physic-chemistry and shading. Additionally, the seed rain under the two plantations was analyzed. The area of spontaneous secondary succession and the area with $T$. micrantha had the highest ligneous plant diversity. The understory of $T$. micrantha plantation had the lowest light intensity and higher late successional species abundance. In addition, $T$. micrantha had higher plant diversity than $S$. molle, which could be explained at least partially by higher diversity in the seed rain. Higher litterfall and mineral content of leaves and twigs of $T$. micrantha did not coincide with higher topsoil mineral content under that species. Instead, soil under S. molle had higher level of $P$ than the soil under $T$. micrantha. Data suggest that a high diversity of ligneous plants could be thrived by the spontaneous succession. On the other hand, $T$. micrantha had promoted a higher richness and abundance of late successional species, which could be related to a more pronounced shade effect, in agreement with the facilitation conception. The lowest diversity and density of ligneous plant species under $S$. molle characterizes an inhibition effect. T. micrantha could be included in restoration plans assembled with other species or combined with areas without intervention, whenever the spontaneous regeneration is possible.

Keywords: Forest restoration, Secondary succession, Shading, Solanum mauriatianum, Schinus terebinthifolius

\footnotetext{
Introduction

In southern and southeastern Brazil, the expansion of monocultures in the last decades brought an increasing reduction and fragmentation of native forests. The Atlantic Forest was reduced to only $7.5 \%$ of its original cover (Myers et al. 2000). In the present time, its cover is highly reduced and fragmented (Ribeiro et al. 2009). The Subtropical Atlantic Forest, also named Seasonal Forest, is an ecoregion of the Atlantic Forest. With an original cover of $1000000 \mathrm{~km}^{2}$ including Brazil, Argentine and Paraguay, nowadays it exhibits only $6 \%$ of that area (Burkart \& Fernández 2002).

The concern with ecosystem restoration in the Atlantic Forest has been recently growing among Brazilian communities and scientists. In such wise, different methods of forest restoration have been investigated (Coelho 2010). Strategies of forest restoration include imitating natural secondary succession, direct seed sowing, monospecific or mixed tree species plantation (Holl et al.
}

(1) UNIJUÍ, Rua do Comércio 3000, Universitário, 98700 000, Ijuí, Rio Grande do Sul (Brazil); (2) Universidade Federal da Fronteira Sul, Av. Presidente Getúlio Vargas 609-N, $2^{\circ}$ andar, Centro, 89812-000, Chapecó, Santa Catarina (Brazil)

\section{@ Geraldo Ceni Coelho (cenicoelho@gmail.com)}

Received: Sep 01, 2011 - Accepted: Nov 28, 2011

Citation: Trindade DFV, Coelho GC, 2012. Woody species recruitment under monospecific plantations of pioneer trees facilitation or inhibition? iForest 5: 1-5 [online 2012-02-06] URL:

http://www.sisef.it/iforest/contents/? id=ifor0601-009

\section{Communicated by: Roberto Tognetti}

turbation occurs. Alternatively, the tolerance model predicts that the later-succession species are able to survive and grow under the presence of the early-succession species, despite the environmental modifications provoked by them (Connell \& Slatyer 1977). The balance between facilitation and competition (inhibition) could be circumstantial and dependent of abiotic factors such as soil nutrient status and moisture (Callaway \& Walker 1997).

Models of restoration based on a heterogeneous pool of tree species of different successional status have been proposed in Brazil over the last two decades (Kageyama et al. 1989, Knowles \& Parrotta 1995, Kageyama \& Gandara 2000) and more recently in Asia (Shono et al. 2007). In these successional models, it is assumed that secondary and shade-tolerant tree species, which present poor (if any) establishment in open and degraded areas, could be favored by the pioneer species through facilitation. However, there is scarce evidence of facilitation in restoration or secondary succession in the Neotropics, and in certain cases the evidences are contrary (Kageyama \& Gandara 2000). Besides, monospecific plantations, particularly some long-lived pioneer tree species, can hinder the return of later successional species (Martínez-Garza \& Howe 2003, Newmaster et al. 2006).

We carried out an assessment of woody plants diversity in the understory of plantations of two native tree species from southern Brazil, Trema micrantha (L.) Blume (Cannabaceae) and Schinus molle L. (Anacardiaceae), in comparison with the spontaneous regeneration observed in an adjacent area. These species are pioneer trees from Neotropics, with fast growth, good adaptation to open areas and also adequate to plantations in degraded sites (Carvalho 
1994, Benvenuti-Ferreira et al. 2009). As pioneer trees with fast initial growth, such species could hypothetically exert a facilitation role when colonizing open areas. Consequently, we expected higher diversity of woody plants under the plantations than in the abandoned area. We tested that hypothesis evaluating the spontaneous regeneration under two plantations of those species, which are established side by side. To elucidate the mechanisms under the differences observed, we had measured: light intensity, seed rain, litterfall, topsoil fertility. We discuss the results in the perspective of the successional model and its underlying hypothesis of facilitation.

\section{Methods}

The investigation was undertaken at the Instituto Regional de Desenvolvimento Rural/ UNIJUÍ, FIDENE, Augusto Pestana, Rio Grande do Sul State, Brazil (28 26' $32^{\prime \prime} \mathrm{S}$ $\left.54^{\circ} 00^{\prime} 12^{\prime \prime} \mathrm{W}\right)$. The soil is a red Oxisoil and the predominant forest is a Subtropical Semi-deciduous Seasonal Forest. The plantations of T. micrantha and $S$. molle were side by side, $3.0 \times 2.0 \mathrm{~m}$ spacing, both established in June 2001. The area was formerly a pasture occupied by dairy cattle. The terrain was subsoiled only in the planting lines. The plantations were established with seedlings $(15-25 \mathrm{~cm}$ height) produced in individual conic containers $\left(75 \mathrm{~cm}^{3}\right)$ in the $\mathrm{Vi}$ veiro Regional, IRDeR/UNIJUÍ, Augusto Pestana, Rio Grande do Sul State, Brazil. Each seedling received $100 \mathrm{~g}$ of granulated NPK fertilizer (04-14-08), which was mixed with the soil around the seedling at the moment of planting. The abandoned area without plantation was adjacent to the two plantations. Trees in plantations of $T$. micrantha showed an average diameter of $52 \pm 12 \mathrm{~cm}$ at $20 \mathrm{~cm}$ above the ground and an average height of around $7.0 \mathrm{~m}$. Trees in plantations of $S$. molle had $43 \pm 11 \mathrm{~cm}$ of diameter at 20 $\mathrm{cm}$ above the ground and near 7.5 meters height on average.

The spontaneous regeneration of ligneous species in the understory of the two plantations and in the shrubby secondary vegetation was measured through a phytosociological survey carried out between April and September 2009, with plots of $2.0 \times 1.3 \mathrm{~m}$. Only ligneous plants with height $>30 \mathrm{~cm}$ were included in the sample. The ligneous plants included trees, shrubs and climbing species. The sampled area was the same in the three sites $\left(104 \mathrm{~m}^{2}\right.$ each). The sample sufficiency has been assessed with the species-point curve. The values of absolute and relative density, frequency and abundance were calculated through usual equations. The Shannon index $H^{\prime}$ has been calculated from the values of relative abundance (Brower et al. 1998).

Species were classified in three successio- nal groups, namely: pioneers, secondary and late successional, corresponding to the classification of Denslow (1980). The light intensity (photosynthetically active radiation) was measured between September 2009 and June 2010, always between 11 and 12 a.m. at a $0.5 \mathrm{~m}$ above the soil, with a light meter device LD-209 Instrutherm ${ }^{\circledR}$. On each date, ten random replications were obtained on each area.

Soil analysis was accomplished from four different samples on each area. Each sample was a mixture of five different subsamples, obtained between 0-10 cm depth. The physico-chemical profile was obtained under the recommendations of Tedesco et al. (1995). Analyses were carried out at the Soil Laboratory of UNIJUí (Ijuí, Rio Grande do Sul State, Brazil).

The mineral content of leaves and twigs of the two planted species was measured on $100 \mathrm{~g}$ samples collected in January 2010 from ten plants of each species. Only twigs and leaves of the last two growth units (less than one year old) were included. The samples were dried in an air forced circulating oven at $40{ }^{\circ} \mathrm{C}$. Chemical data were provided by the UFRGS Laboratory (Porto Alegre, Rio Grande do Sul State, Brazil) through methods recommended by Tedesco et al. (1995).

Litterfall was estimated through ten traps of $0.5 \times 0.5 \mathrm{~m}$ on each plantation area during the year 2004. The values were expressed in dry weight basis.

The seed rain was estimated with 30 circular traps with $0.25 \mathrm{~m}$ of diameter on each plantation, amounting $1.47 \mathrm{~m}^{2}$ on each area.
Tab. 1 - Abundance and diversity data of ligneous plant species from the understory of T. micrantha (TM), understory of $S$. molle (SM), and spontaneous secondary regeneration area (SV).

\begin{tabular}{lccc}
\hline \multicolumn{1}{c}{ Parameters } & TM & SM & SV \\
\hline Individuals & 105 & 17 & 119 \\
H' (Shannon) & 1.40 & 1.06 & 1.67 \\
Species & 14 & 5 & 12 \\
Pioneer & 6 & 4 & 8 \\
Secondary & 4 & 1 & 3 \\
Late successional & 4 & - & 1 \\
\hline
\end{tabular}

The trapped seeds were gathered monthly between December 2009 and November 2010.

\section{Results}

Richness and abundance of ligneous plant species were higher under $T$. micrantha (TM) and in the spontaneous vegetation (SV) than under S. molle (SM). The proportion of secondary and late successional species was higher in TM (Tab. 1).

In all areas, twenty different species were recorded in the phytosociological inventory and four additional species were recorded out of the plots (Tab. 2). Among them, Hovenia dulcis and Morus nigra are exotic species.

Similarity among the studied areas was very low. Only $S$. terebinthifolius was shared in between TM and SM. Between SM and $\mathrm{SV}$ areas there were three species in com-

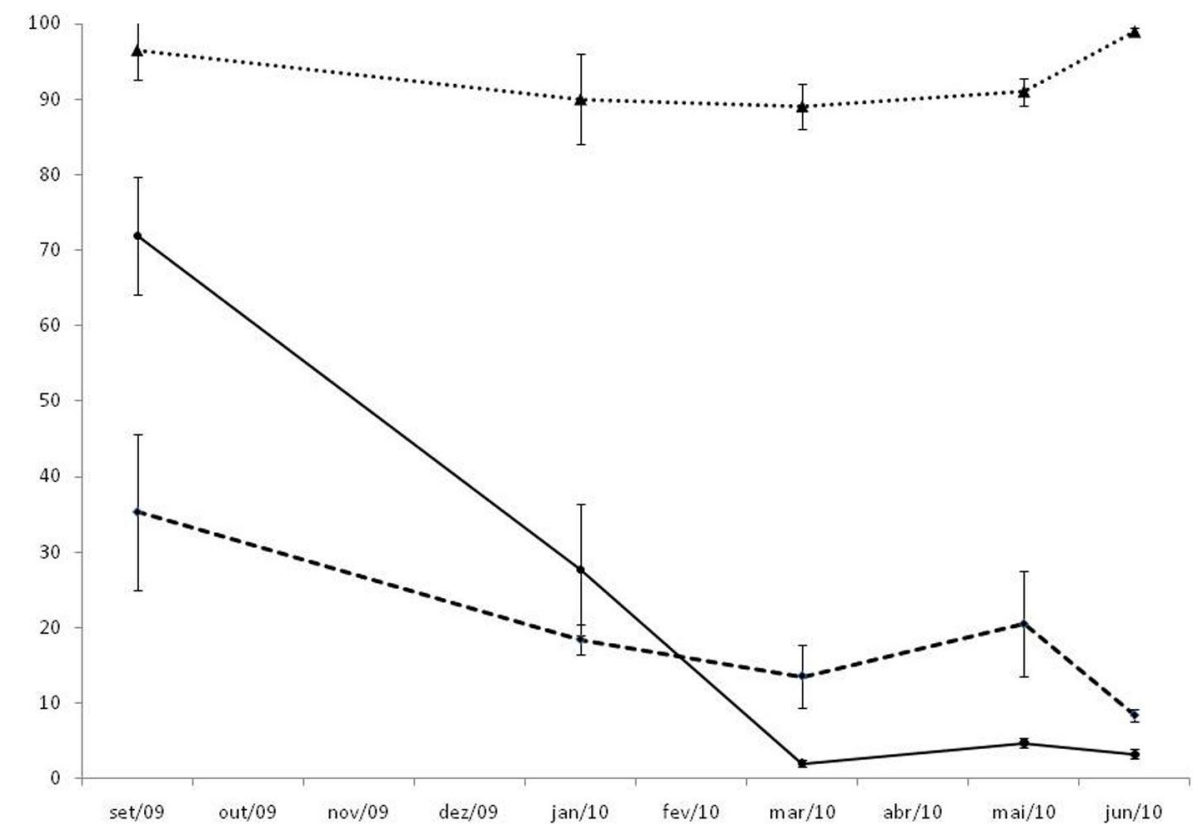

Fig. 1 - Light intensity (\% of the full sun light) between September 2009 and June 2010, under T. micrantha (solid line) and S. molle (dashed line) plantations, and in the spontaneous secondary regeneration (triangles, dotted line). Vertical bars indicate standard error. 
Tab. 2 - Mechanism of dispersion (DM) and relative abundance (expressed as percentage) of ligneous plant species from the understory of $T$. micrantha (TM), understory of $S$. molle $(\mathrm{SM})$, and spontaneous secondary regeneration area (SV), for each successional guild. (Z): zoochoric; (A): autochoric; (W): wind-dispersed; (?): unknown; (-): absent; (•): observed out of the plots.

\begin{tabular}{|c|c|c|c|c|}
\hline Species & DM & $\mathbf{T M}$ & SM & SV \\
\hline \multicolumn{5}{|l|}{ Pioneer } \\
\hline Schinus terebenthifolius Raddi & $\mathrm{Z}$ & 58 & 37.5 & 6.7 \\
\hline Ocotea puberula (Rich.) Ness. & $\mathrm{Z}$ & 14.5 & - & - \\
\hline Baccharis punctulata DC & $\mathrm{W}$ & 11 & - & 2.5 \\
\hline Senna macranthera (DC ex Colland.) Irwin \& Barneby & $?$ & 1 & - & - \\
\hline Baccharis dracunculifolia DC & $\mathrm{W}$ & - & 50 & 18.5 \\
\hline Aegiphila brachiata Vell. & $\mathrm{Z}$ & - & 6.3 & 1.7 \\
\hline Solanum mauritianum Scop. & $\mathrm{Z}$ & - & - & 44.5 \\
\hline Morus nigra $\mathrm{L}$. & $\mathrm{Z}$ & - & - & 1.7 \\
\hline Schinus molle L. & $\mathrm{Z}$ & - & - & 1.7 \\
\hline Acacia recurva Bentham & $\mathrm{A}$ & • & - & 0.8 \\
\hline Hovenia dulcis Thunberg & $\mathrm{Z}$ & - & - & - \\
\hline \multicolumn{5}{|l|}{ Secondary } \\
\hline Nectandra lanceolata Ness & Z & - & 6.3 & - \\
\hline Zanthoxylum rhoifolium Lam. & $\mathrm{Z}$ & 3.0 & - & - \\
\hline Celtis iguaneae (Jacq.). Sargent & $\mathrm{Z}$ & 1.0 & - & - \\
\hline Matayba elaeagnoides Radlk. & $\mathrm{Z}$ & - & - & 17.7 \\
\hline Cupania vernalis Camb. & $\mathrm{Z}$ & 1.0 & - & 2.5 \\
\hline Gledtisia amorphoides (Griseb.) Taubert & $?$ & - & - & 0.8 \\
\hline Prunus myrtifolia (L.) Urban & $\dot{Z}$ & • & - & - \\
\hline Rollinia salicifolia Schltdl. & $\mathrm{Z}$ & - & • & - \\
\hline \multicolumn{5}{|l|}{ Late successional } \\
\hline Trichilia elegans A. Juss. & Z & 7.5 & - & - \\
\hline Trichilia catigua A. Juss. & $\mathrm{Z}$ & 2.0 & - & - \\
\hline Allophylus edulis (A. St.-Hil., Camb. \& A. Juss.) & $\mathrm{Z}$ & 1.0 & - & - \\
\hline Allophylus guaraniticus A. St.-Hil. & $\mathrm{Z}$ & - & - & 0.8 \\
\hline Ilex paraguariensis A. St. Hil. & $\mathrm{Z}$ & • & - & - \\
\hline
\end{tabular}

Tab. 3 - Physico-chemical soil profile in the top soil $(0-10 \mathrm{~cm})$ under T. micrantha and $S$. molle plantations, and in the spontaneous secondary regeneration. Different letters among columns indicate significant differences after Tukey's test $(P<0.05)$.

\begin{tabular}{lclrlrl}
\hline Mineral & Trema micrantha & Schinus molle & $\begin{array}{c}\text { Spontaneous } \\
\text { vegetation }\end{array}$ \\
\hline $\mathrm{P}$ & 7.1 & $\mathrm{~b}$ & 10.6 & $\mathrm{a}$ & 3.7 & $\mathrm{c}$ \\
$\mathrm{K}$ & 110 & $\mathrm{a}$ & 123.8 & $\mathrm{a}$ & 140.5 & $\mathrm{a}$ \\
$\mathrm{S}\left(\mathrm{mg} / \mathrm{dm}^{3}\right)$ & 2 & $\mathrm{a}$ & 1.5 & $\mathrm{a}$ & 6.3 & $\mathrm{~b}$ \\
$\mathrm{Cu}$ & 10.8 & $\mathrm{~b}$ & 11.7 & $\mathrm{~b}$ & 8.5 & $\mathrm{a}$ \\
$\mathrm{Zn}$ & 3.2 & $\mathrm{ab}$ & 4.3 & $\mathrm{a}$ & 2.5 & $\mathrm{~b}$ \\
$\mathrm{Mn}$ & 77.8 & $\mathrm{a}$ & 64.6 & $\mathrm{a}$ & 38.6 & $\mathrm{a}$ \\
$\mathrm{Al}$ & 0.2 & $\mathrm{a}$ & 0.1 & $\mathrm{a}$ & 0.1 & $\mathrm{a}$ \\
$\mathrm{Ca}\left(\mathrm{cmolc} / \mathrm{dm}^{3}\right)$ & 5.4 & $\mathrm{a}$ & 6.6 & $\mathrm{ab}$ & 8.1 & $\mathrm{~b}$ \\
$\mathrm{Mg}$ & 2.1 & $\mathrm{a}$ & 2.2 & $\mathrm{a}$ & 4.3 & $\mathrm{~b}$ \\
$\mathrm{pH}$ & 5.15 & $\mathrm{a}$ & 5.4 & $\mathrm{a}$ & 5.65 & $\mathrm{a}$ \\
$\mathrm{CEC}(\mathrm{pH}=7.0)$ & 13.9 & $\mathrm{a}$ & 14.0 & $\mathrm{a}$ & 18.5 & $\mathrm{~b}$ \\
$\mathrm{~V} \%$ & 54.3 & $\mathrm{a}$ & 64.7 & $\mathrm{ab}$ & 69 & $\mathrm{~b}$ \\
$\mathrm{M} \%$ & 3 & $\mathrm{a}$ & 1.4 & $\mathrm{a}$ & 0.6 & $\mathrm{a}$ \\
$\mathrm{O} \% \mathrm{M} .(\%)$ & 3.5 & $\mathrm{a}$ & 3.6 & $\mathrm{a}$ & 3.2 & $\mathrm{a}$ \\
\hline
\end{tabular}

mon, all of them were pioneers. TM and SV presented four species in common, three pioneers and one secondary (Tab. 2).

The zoochory predominates, corresponding to 19 species or $79 \%$ of the ligneous flora (Tab. 2). leaves in T. micrantha. The leaf cover was restored during the summer, so that the light intensity in March onwards was lower in TM plantation (Fig. 1).

Litter production (dry weight) was higher under TM than under SM $\left(677 \mathrm{~g} \mathrm{~m}^{-2}\right.$ year ${ }^{-1}$ and $325 \mathrm{~g} \mathrm{~m}^{-2}$ year $^{-1}$, respectively). Data on litterfall in the spontaneous vegetation were not available.

The mineral contents of the soil are higher in the SV area for $\mathrm{S}, \mathrm{Ca}$ and $\mathrm{Mg}$. SV also have larger values of CEC and base saturation (Tab. 3). The plantations of TM and SM had higher levels of $\mathrm{Cu}$ and P. The SM area showed elevated values of $\mathrm{Zn}$ (Tab. 3).

The mineral content of leaves and twigs of T. micrantha was higher than of S. molle as a general rule (Tab. 4).

The seed rain in the plantation of $T$. $m i-$ crantha included 34 seeds of six different species, corresponding to 23.1 seeds $\mathrm{m}^{-2}$ year $^{-1}$. Under the $S$. molle plantation, a total of five seeds of four different species were collected, which accounts for 3.4 seeds $\mathrm{m}^{-2}$ year-1 (Tab. 5).

Sebastiana commersoniana (Baill.) Smith $\&$ Downs and Celtis iguanae (Jacq.) Sarg.

Tab. 4 - Mineral contents of leaves and twigs of T. micrantha and S.molle. From N to $\mathrm{S}$ data as a percentage, from $\mathrm{Cu}$ to $\mathrm{Al}$ data as ppm. $(*)$ : significant differences $(P<0.05)$ after Tukey's test.

\begin{tabular}{lccc}
\hline Mineral & $\begin{array}{c}\text { S. } \\
\text { molle }\end{array}$ & $\begin{array}{c}\boldsymbol{T} \text {. } \\
\text { micrantha }\end{array}$ & Prob. \\
\hline $\mathrm{N}$ & 1.6 & 3.7 & $*$ \\
$\mathrm{P}$ & 0.24 & 0.26 & n.s. \\
$\mathrm{K}$ & 1.48 & 2.16 & $*$ \\
$\mathrm{Ca}$ & 1.21 & 1.82 & $*$ \\
$\mathrm{Mg}$ & 0.25 & 0.57 & $*$ \\
$\mathrm{~S}$ & 0.14 & 0.16 & $*$ \\
$\mathrm{Cu}$ & 8.6 & 7 & n.s. \\
$\mathrm{Zn}$ & 25.2 & 23.4 & n.s. \\
$\mathrm{Fe}$ & 91.2 & 165.8 & $*$ \\
$\mathrm{Mn}$ & 161.4 & 383 & $*$ \\
$\mathrm{Al}$ & 61.6 & 83.4 & n.s. \\
\hline
\end{tabular}

Tab. 5 - Seed rain under the plantations of Trema micrantha and Schinus molle. The seeds of $T$. micrantha and $S$. molle were excluded.

\begin{tabular}{lcc}
\hline \multicolumn{1}{c}{ Species } & $\boldsymbol{T}$. & $\boldsymbol{S}$. \\
micrantha & molle \\
\hline Schinus terebinthifolius & 25 & 1 \\
Cupania vernalis & 5 & - \\
Sebastiana commerso- & 1 & 1 \\
niana & & \\
Ilex paraguariensis & 1 & - \\
Celtis iguanae & 1 & - \\
Trichilia cf. elegans & 1 & - \\
Zanthoxylum sp. & - & 2 \\
Unidentified & - & 1 \\
Total & 34 & 5 \\
\hline
\end{tabular}


were observed among collected seeds, but no individuals of these species were found among saplings. Data on seed rain in the spontaneous vegetation were not available.

\section{Discussion}

The spontaneous succession and the plantation of $T$. micrantha promoted highest ligneous species diversity. However, the floristic composition was clearly different among them. The proportion of secondary and late successional species was higher under $T$. micrantha, which probably is related to more shaded conditions. Regeneration under $T$. micrantha indicates facilitation to species such as Ocotea puberula and Trichilia elegans, while an inhibition effect should be considered for others, e.g., Matayba eleagnoides, Solanum mauritianum and Baccharis dracunculifolia. Our results are in contrast with those from Butler et al. (2008), who reported a systematic lower diversity in the spontaneous regeneration compared to plantations. A possible explanation may lie in the former land use of the study areas. In our investigation, the area with natural regeneration was a cattle pasture with low animal densities, while in the study of Butler et al. the land activity was rice production, followed by cattle pastures. Past land use is de cisive to the quality and rate of regeneration (Uhl et al. 1988).

The presence of exotic species did not differentiate the areas, and could be considered low, as only two individuals (of two different species) were observed.

The soil chemical profiles indicate that plantations present lower levels of important nutrients in the topsoil, for instance $\mathrm{Ca}, \mathrm{Mg}$ and $\mathrm{S}$, and also lower levels of $\mathrm{V} \%$ and CEC. On the other hand, they had higher levels of $\mathrm{P}$, which could be due to fertilizer addition at the moment of planting. Lower levels of $\mathrm{Ca}$ and $\mathrm{Mg}$ in the topsoil under plantations (and $\mathrm{V} \%$ in the case of $\mathrm{TM}$ ) could be due to the movement of the bases from soil to the aboveground biomass due to fast growth of the plantations.

In early stages of the secondary succession, sites with higher fertility can exhibit higher diversity (Finegan \& Delgado 2000). However, lower levels of nutrients only hardly could explain a lower diversity under $S$. molle, which had lower diversity and density of woody recruits than $T$. micrantha plantation, in spite of equivalent levels of nutrients in the topsoil (except for P, which was larger in $S$. molle sites).

Moreover, the diversity tends to increase along the secondary succession, in spite of reduction of nutrients in the topsoil (Coelho et al. 2011). In tropical mature forests, differences in floristic composition and $\mathrm{di}$ versity could be related to soil fertility, with a negative correlation between diversity and nutrient levels (Huston 1980, Paoli et al.
2006).

The light intensity under $S$. molle was intermediate, so that factor was probably not the cause of its lower diversity and abundance of saplings. Two alternative explanations to the low diversity and abundance of woody species could be invoked, namely: the differences in the seed rain and the existence of allelopathy. Total number of propagules in seed rain was more than six times higher under $T$. micrantha than under $S$. molle, which partially could have contributed to the higher diversity in the first.

Low diversity under $S$. molle could also be related to allelopathy. $S$. molle presents high contents of allelochemicals with noteworthy biological activities (Gebre-Amlak \& Azerefegne 1999) and in vitro allelopathy (Materechera \& Hae 2008, Zahed et al. 2010). The increment in fertility combined with inhibitory effects (and low plant diversity) was also observed under plantations of Pinus taeda L. and Eucalyptus viminalis Labill. (Gonçalves et al. 2003). Notwithstanding, allelopathic effects in the field are a matter of controversy, and usually difficult to be distinguished from other mechanisms of negative interference, such as competition for nutrients and water (Royo \& Carson 2006). New experimental research on the allelopathic potential of fast-growth pioneer tree species is decisive to understand the secondary succession and to the perspective of tree plantations as a strategy to improve forest restoration.

The seed rain intensity was higher under $T$. micrantha plantation, which demonstrates that species can differ in their attractiveness to the seed dispersers. The zoochory was the predominant mechanism in regeneration of the experimental area (79\% of the species), slightly larger to other reports from Seasonal Semi-deciduous Forests from southern Brazil (63-77 \% - Nascimento et al. 2000, Giehl et al. 2007, Ruchel et al. 2007). Nevertheless, the observed rate of 23 seeds $\mathrm{m}^{-2}$ year ${ }^{-1}$ can be considered low. In the same ecoregion, perches installed in an abandoned pasture presented 106 seeds $\mathrm{m}^{-2}$ year $^{-1}$ (Pillatt et al. 2010). In other ecoregion of the Atlantic Forest, a seed rain intensity of 181 seeds $\mathrm{m}^{-2}$ year ${ }^{-1}$ was observed under perches (Vicente et al. 2010).

As a low-cost alternative to restoration, spontaneous secondary succession could be recommended to sites without hampering factors, such as weed invasion or absence of seeds source. On the other hand, the use of pioneer tree species such as $T$. micrantha could facilitate the establishment of other tree species, especially the late successional ones. Whenever possible, the combination of plantation with facilitation properties and abandonment, side by side, could promote higher diversity in degraded areas.

\section{Conclusions}

The diversity of woody plants under the plantations of $S$. molle was lower than spontaneous regeneration and under $T$. micrantha plantation, which configures an inhibition.

T. micrantha could favor the recruitment of certain late successional woody species, and its plantation could contribute to accelerate the secondary succession.

T. micrantha present higher values of litterfall and mineral content in the leaves when compared with $S$. molle, but the topsoil under T. micrantha present lower levels of $\mathrm{P}$, indicating that the process of transference of mineral nutrients from the soil to the aboveground biomass could overcome the return via litterfall.

T. micrantha presents higher values of seed rain of woody species when compared with S. molle.

\section{Acknowledgements}

César O. Sartori and Jorge Schirmer (IRDeR, UNIJUÍ) helped with logistical support. Mara Rejane Ritter and Angelo Schneider (UFRGS) collaborated with taxonomic assistance. Universidade Regional do Noroeste do Estado do Rio Grande do Sul UNIJUÍ provided work support and infrastructure to the investigation activities of the authors. Universidade Federal do Rio Grande do Sul - UFRGS helped with the chemical analyses. Andressa P. Felipin has reviewed the English.

\section{References}

Benvenuti-Ferreira G, Coelho GC, Schirmer J, Lucchese OA (2009). Dendrometry and litterfall of neotropical pioneer and early secondary tree species. Biota Neotropica 9: 65-71. - doi: 10.1590/S1676-06032009000100008

Brower JE, Zar JH, Ende CN (1998). Field and laboratory methods for general ecology ( $\left.4^{\text {th }} \mathrm{edn}\right)$. McGraw-Hill, EUA, pp. 273.

Burkart R, Fernández JG (2002). Introducción. In: "La Selva Misionera - opciones para su conservación y uso sustentable" (Burkart R, Cinto JP, Chébez JC, Fernández JG, Riegelhaupt $\mathrm{E}$ eds). FUCEMA, Buenos Aires, Argentina, pp. 11-16. Butler R, Montagnini F, Arroyo P (2008). Woody understory plant diversity in pure and mixed native tree plantations at La Selva Biological Station, Costa Rica. Forest Ecology and Management 255: 2251-2263. - doi: 10.1016/j.foreco. 2007.12.050

Callaway RM, Walker LR (1997). Competition and facilitation: a synthetic approach to interactions in plant communities. Ecology 78: 19581965. - doi: 10.1890/0012-9658(1997)078[1958: CAFASA]2.0.CO;2

Camargo JLC, Ferraz IDK, Imakawa AM (2002). Rehabilitation of degraded areas of Central Amazonia using direct sowing of forest tree seeds. Restoration Ecology 10: 636-644. - doi: 10.1046/j.1526-100X.2002.01044.x

Carlo TA, Collazo JA, Groom MJ (2003). Avian 
fruit preferences across a Puerto Rican forested landscape: pattern consistency and implications for seed removal. Oecologia 134: 119-131. - doi: 10.1007/s00442-002-1087-1

Carvalho PER (1994). Espécies florestais brasileiras: recomendações silviculturais, potencialidades e uso da madeira. EMBRAPA-CNPF Brasília, Brazil.

Coelho GC (2010). Restauração florestal em pequenas propriedades: desafios e oportunidades. In: "Gestão ambiental nos municípios: instrumentos e experiências na administração pública" (Hüller A ed). FURI, Santo Angelo, Brazil, pp. 195-215.

Coelho GC, Rigo MS, Libardoni JB, Oliveira R, Benvenuti-Ferreira G (2011). Understory structure in two successional stage of Semi-deciduous seasonal forest remnant of Southern Brazil. Biota Neotropica 11: [online] URL: http://www.biotaneotropica.org.br/v11n3/en/abstract? article+bn01011032011.

Connell JH, Slatyer RO (1977). Mechanisms of succession in natural communities and their role in community stability and organization. American Naturalist 111: 1119-1144. - doi: 10.1086/ 283241

Denslow JS (1980). Gap partitioning among tropical rain forest trees. Biotropica 12: 47-55. doi: $10.2307 / 2388156$

Finegan B, Delgado D (2000). Structural and floristic heterogeneity in a 30-year-old Costa Rican rain forest restored on pasture through natural secondary succession. Restoration Ecology 8: 380-393. - doi: 10.1046/j.1526-100x.2000. 80053.x

Gebre-Amlak A, Azerefegne F (1999). Insecticidal activity of chinaberry, endod and pepper tree against the maize stalk borer (Lepidoptera: Noctuidae) in Southern Ethiopia. International Journal of Pest Management 45: 9-13. - doi: 10.1080/096708799227987

Giehl ELH, Athayde EA, Budke JC, Gesing JPA, Einsiger SM, Canto-Dorow TS (2007). Espectro e distribuição vertical das estratégias de dispersão de diásporos do componente arbóreo em uma floresta estacional no sul do Brasil. Acta Botanica Brasilica 21: 137-145. - doi: 10.1590/ S0102-33062007000100013

Gonçalves JLM, Nogueira LR, Ducatti F (2003). Recuperação de solos degradados. In: "Restauração ecológica de ecossistemas naturais" (Kageyama PY, Oliveira RE, Moraes LFD, Engel VL, Gandara FB eds). FEPAF, Botucatu, Brazil, pp. 111-163

Holl KD, Loik ME, Lin EH, Samuels IA (2000). Tropical montane forest restoration in Costa Rica: overcoming barriers to dispersal and esta- blishment. Restoration Ecology 8: 339-349. doi: 10.1046/j.1526-100x.2000.80049.x

Huston M (1980). Soil nutrients and tree species richness in Costa Rican forests. Journal of Biogeography 7: 147-157. - doi: 10.2307/ 2844707

Kageyama PY, Castro CFA, Carpanezzi AA (1989). Implantação de matas ciliares: estratégia para auxiliar a sucessão secundária. In: "Simpósio sobre mata ciliar" (Barbosa LM ed). Fundação Cargill, Campinas, Brazil, pp. 130143.

Kageyama PY, Gandara FB (2000). Recuperação de áreas ciliares. In: "Mata ciliares: uma abordagem multidisciplinar" (Rodrigues RR, Leitão Filho HF eds). EDUSP/FAPESP, São Paulo, Brazil, pp. 249-269.

Knowles OH, Parrotta JA (1995). Amazonian forest restoration: an innovative system for native species selection based on phenological data and field performance indices. Commonwealth Forestry Review 74: 230-243.

Martínez-Garza C, Howe HF (2003). Restoring tropical diversity: beating the time tax on species loss. Journal of Applied Ecology 40: 423-429. doi: 10.1046/j.1365-2664.2003.00819.x

Materechera SA, Hae ME (2008). Potential of aqueous extracts from parts of the pepper tree (Schinus molle L.) to affect emergence and seedling development of wheat (Triticum sativa L.) and weeds in a manure amended soil. The Open Agriculture Journal 2: 99-104. - doi: 10.2174/ 1874331500802010099

Myers N, Mittermeier RA, Mittermeier CG, Fonseca GAB, Kent J (2000). Biodiversity hotspots for conservation priorities. Nature 403: 853-858. - doi: 10.1038/35002501

Nascimento ART, Longhi SJ, Alvarez-Filho A, Gomes GS (2000). Análise da diversidade florística e dos sistemas de dispersão de sementes em um fragmento florestal na região central do Rio Grande do Sul, Brasil. Napaea 12: 49-67.

Newmaster SG, Bell FW, Roosenboom CR, Cole HA, Towill WD (2006). Restoration of floral diversity through plantations on abandoned agricultural land. Canadian Journal of Forest Research 36: 1218-1235. - doi: 10.1139/x06-021

Paoli GD, Currant LM, Zak DR (2006). Soil nutrients and beta diversity in the Bornean Dipterocarpaceae: evidence for niche partitioning by tropical rain forest trees. Journal of Ecology 94: 157-170. - doi: 10.1111/j.1365-2745.2005. 01077.x

Parrotta JA, Knowles OH (1999). Restoration of tropical moist forests on bauxite-mined lands in the Brazilian Amazon. Restoration Ecology 7:
103-116. - doi: 10.1046/j.1526-100X.1999 72001.x

Pillatt N, Pillatt N, Franco ETH, Coelho GC (2010). Dry artificial perches and the seed rain in a subtropical riparian forest. Revista Brasileira de Biociências 7: 246-252.

Reis A, Bechara FC, Espíndola MB, Vieira NK, Souza LL (2003). Restoration of damaged land areas: using nucleation to improve successional processes. Natureza \& Conservação 1: 85-92.

Ribeiro MC, Metzger JP, Martensen AC, Ponzoni FJ, Hirota MM (2009). The Brazilian Atlantic Forest: how much is left, and how is the remaining forest distributed? Implications for conservation. Biological Conservation 142: 1141-1153. - doi: 10.1016/j.biocon.2009.02.021

Royo AA, Carson WP (2006). On the formation of dense understory layers in forests worldwide: consequences and implications for forest dynamics, biodiversity, and succession. Canadian Journal of Forest Research 36: 1345-1362. - doi: 10.1139/x06-025

Ruchel RA, Nodari RO, Moerschbacher BM (2007). Woody plant species richness in the Turvo State Park, a large remnant of deciduous Atlantic forest, Brazil. Biodiversity and Conservation 16: 1699-1714. - doi: 10.1007/s10531006-9044-7

Ruiz-Jaén MC, Aide TM (2005). Vegetation structure, species diversity, and ecosystem processes as measures of restoration success. Forest Ecology and Management 218: 159-173. - doi: 10.1016/j.foreco.2005.07.008

Shono K, Davies SJ, Chua YK (2007). Performance of 45 native tree species on degraded lands in Singapore. Journal of Tropical Forest Science 19: $25-34$.

Tedesco MJ, Gianello C, Bissani CA, Bohnen H, Volkweiss SJ (1995). Análise de solo, plantas e outros materiais. Boletim técnico no. 5, Departamento de Solos/UFRGS, Porto Alegre, Brazil.

Uhl C, Buschbacher R, Serrão EAS (1988). Abandoned pastures in Eastern Amazonia. I. Patterns of plant succession. Journal of Ecology 76: 663681. - doi: 10.2307/2260566

Vicente R, Martins R, Zocche JJ, Harter-Marques B (2010). Seed dispersal by birds on artificial perches in reclaimed areas after surface coal mining in Siderópolis municipality, Santa Catarina State, Brazil. Revista Brasileira de Biociências 8: 14-23.

Zahed N, Hosni K, Brahim NB,Kallel M, Sebei H (2010). Allelopathic effect of Schinus molle essential oils on wheat germination. Acta Physiologiae Plantarum 32: 1221-1227. - doi: 10.1007/ s1 1738-010-0492-z 